\title{
Analytical Model of Thermal Runaway in Alkaline Batteries
}

\author{
Nikolay E. Galushkin*, Nataliya N. Yazvinskaya, Dmitriy N. Galushkin \\ Don State Technical University, Laboratory of electrochemical and hydrogen energy, 147 Shevchenko \\ Street, Town of Shakhty, Rostov Region, Russia, 346500. \\ *E-mail: galushkinne@mail.ru
}

doi: $10.20964 / 2018.02 .47$

Received: 7 November 2017 / Accepted: 13 December 2017 / Published: 28 December 2017

\begin{abstract}
In this study, there was first developed an analytical model of thermal runaway in alkaline batteries. The model was constructed based on the thermal runaway new mechanism experimentally deduced by us in our previous works proving that the thermal runaway was connected with initiation of a powerful exothermic reaction of atomic hydrogen recombination. It was shown that the equations obtained from the model for current and voltage changes on battery terminals during a thermal runaway correspond to experimental data with the relative error not more than $4.2 \%$.
\end{abstract}

Keywords: model, thermal runaway, battery, nickel-cadmium, exothermic reaction

\section{$\underline{\text { FULL TEXT }}$}

(C) 2018 The Authors. Published by ESG (www.electrochemsci.org). This article is an open access article distributed under the terms and conditions of the Creative Commons Attribution license (http://creativecommons.org/licenses/by/4.0/). 